\title{
The Instant Composers Pool: Music Notation and the Mediation of Improvising Agency

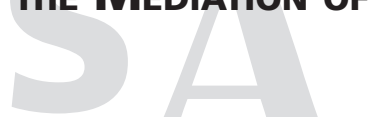

Floris Schuiling ${ }^{1}$

Utrecht University, The Netherlands

\begin{abstract}
This article relates the recent development of a "relational musicology" to debates about participatory art and relational aesthetics. I present results from an ethnographic study of the Dutch improvising music collective the Instant Composers Pool, founded in 1967 and still performing. With a background in jazz, experimental music and performance art, this group developed an improvisatory musical practice in which musical notations are freely used. These pieces mediate the social and creative agency of the musicians in the group. As such, they provide a case for reconsidering the nature of musical notation, and the distinction between composition and improvisation, which have been foundational for the academic study of music, and constitutive for a distinction between the aesthetic and the social. I employ the concept of "microtopia" to describe not only the way in which artistic practices subvert such conventional categories, but also to account for the value of ethnographic fieldwork to take such practices as inspiration for disciplinary innovation.
\end{abstract}

Keywords: improvisation, music notation, relational musicology, mediation, ontology, creativity

Just as relational aesthetics in recent years has come to signify a convergence of art history and theory with the anthropology of art, so has the recently emerged "relational musicology" reflected on and advocated an interdisciplinary encounter between musicology and ethnomusicology (Born 2010, Cook 2012). Despite different genealogies, these two encounters raise much the same questions: how can we understand artistic and musical practices as shaping social relations? How have previous academic definitions of art and music prevented such un-

1 Institute for Cultural Enquiry, Faculty of the Humanities, Institute for Cultural Enquiry. This research was part of a doctoral project conducted as a member of Corpus Christi College, Cambridge, at the music faculty of the University of Cambridge. The project was made possible through support from the UK Arts and Humanities Research Council, the Cambridge Home and EU Scholarship Scheme and Corpus Christi College, and aided by grants from the Music \& Letters Trust, the Society for Music Analysis and the William Barclay Squire Fund. For further results from this project, see Schuiling (2015). Author’s contact email: f.j.schuiling@uu.nl. 
derstanding? How does the entanglement of such microscopic practices in wider social and historical processes compromise or amplify their political efficacy? Despite such similarities, and notwithstanding a proclaimed openness about their respective subject matter, these two interdisciplines have shown little mutual engagement (Born, Lewis and Straw (forthcoming) engages with relational art from a musicological perspective). However, they seem to have much to offer each other. For one, the relational aesthetics and the anthropology of art have a much closer engagement with recent anthropological theory than ethnomusicology (Kingsbury 1997, Beginho 2008). In particular, the influence of material culture, as exemplified in the work of Alfred Gell (1998) and its lasting influence on this field, opens up interesting new perspectives when applied to music. Conversely, relational musicology, with its background in ethnomusicology, can draw on a long tradition in this field to study music as a form of social interaction, since for many ethnomusicologists a theory of music is implicitly a theory of social practice.

In this article I present some results from an ethnographic research project on the Instant Composers Pool Orchestra, an improvisation collective based in Amsterdam that has built a global reputation as one of the most innovative groups in improvised music, and performs regularly around the world. ${ }^{2}$ It was founded as the Instant Composers Pool (ICP) in 1967 by pianist and composer Misha Mengelberg, clarinettist and saxophonist Willem Breuker, and drummer Han Bennink. Influenced by free jazz, contemporary art music, experimental music and the performances of Fluxus and Happenings, the group developed not only a diverse and distinctive sound, but also a particular musical practice that integrated compositional and improvisatory aspects. This performance practice was developed against a backdrop of an emerging counter-culture. Their musical practice and the concept of "instant composition" was an attempt to democratise musical performance by musicians who did not believe in "freedom" in improvisation, yet were critical of the traditional hierarchy between composer and performer.

The field of musicology, with its roots as a philological discipline uncovering and editing the music of the past, has proceeded from an ontological assumption that music exists as "works", i.e. ideal Platonic objects represented by musical notation (Cook 2001, 2014). The practice of the ICP, which uses a variety of musical notations in the improvisatory process, constitutes a wholly different ontology of music as it imagines a radically different relation between notation and the resulting sound. ${ }^{3}$ Their notations function as mediators of the social and crea-

2 The Orchestra members during my fieldwork were Misha Mengelberg (piano), Han Bennink (drums), Ernst Glerum (double bass), Tristan Honsinger (cello), Mary Oliver (violin/viola), Wolter Wierbos (trombone), Tobias Delius (tenor saxophone/clarinet), Ab Baars (tenor saxophone/clarinet), Michael Moore (alto saxophone/clarinet), Thomas Heberer (trumpet/cornet). In addition, pianist and organist Guus Janssen frequently performed with the group.

3 Although I am aware of the interest in ontology in contemporary anthropological theory, and will relate ethnography and ontology later in the text, my interest in ontology initially arose because of developments in musicology. Lydia Goehr's The Imaginary Museum of Musical Works (2007 [1992]) argued that the work-based ontology of music was a historically emergent, culturally specific regulative ideal rather than a natural category. The targets of her criticism were not primarily musicologists (whose work-based methodologies she did include in her critique) but philosophers, who saw the question 'what is a musical work' as being particularly interesting for analytic philosophy, as it implies an ideal object that is nonetheless created at a specific point in time and knows various instantiations in performance that are different to each other as much as to its notation. Such questions were usually answered by logical stipulations about the relation of notation to particular performances. Goehr's argument was enthusiastically received by musicologists who, as I explain later in the text, were seeking alternatives to their workbased paradigm. In one of the key texts on this development, Philip Bohlman (1999) called for a pluralisation of musical ontologies - which, he is careful to point out, do not map on to musical 'cultures' but may exist at both a local and a global level. Bohlman suggests two axes, one between product and process and one between embeddedness 
tive agency of the ICP's musicians. As such they also require a reconsideration of improvisation.

Musical improvisation has been one of the fields in which the creativity of performers and the idea of music as a relational practice have received the most attention. However, improvisation has mostly been described in opposition to the use of notations, and this has often been connected to utopian claims of collectivity. Daniel Fischlin and Ajay Heble, for instance, write that improvisational practices have generally shown "concepts of alternative community formation, social activism, rehistoricization of minority cultures, and critical modes of resistance and dialogue" (2004: 2). More recently, and with the increased attention to improvised music in music scholarship, such claims have started to be criticised, as such descriptions of improvised music are inherently bound up with the status of improvisation as the "Other" to the Western, written tradition of art music (Nooshin 2003, Prouty 2006). Such criticisms call for a greater empirical attention to a diversity of musical practices and to the ways in which particular social relations are enacted in each of them (Cook 2007, Labaree 2013, Stanbridge 2008). As Claire Bishop asks of Bourriaud, if we accept that art produces social relations, then we must ask "what types of relations are being produced, for whom, and why?" (Bishop 2004: 65)

In what follows I will first describe some of the background to relational musicology: this will familiarise some readers with the issues at hand, serve to introduce the role of notation in the distinction between musicology and ethnomusicology, and help describe my view of the theme of "microtopias" (Bourriaud 2002: 31), especially as it relates to the purpose of ethnography. After a brief sketch of the history and musical approach of the ICP Orchestra, I will present some more detailed examples from my fieldwork to describe the function of notations in their practice. To conclude, I will draw out some of the themes of my discussion that relate most directly to the concerns of relational aesthetics.

\section{Ethnomusicology and Relational Musicology}

Conventional ways of distinguishing ethnomusicology from musicology either focus on the subject matter- "world musics" rather than western art music —or on the main method of study - ethnographic rather than historical. Gary Tomlinson (2012) argues that a distinction between the two fields can be traced back to the late eighteenth century, about a century before the respective academic disciplines were formally founded. With the rise of Kantian aesthetics, in which the formal properties of art rather than its content were argued to be "truly aesthetic", instrumental music rose greatly in esteem. Tomlinson notes that before, song was the primary category of music, considered a basic aspect of human expression, common to people around the world. The aesthetics of Kant paved the way for the idea that music, as opposed to song, exemplified the historical progress of European culture. Contemporaneous music histories in addition defined the music-historical development of a culture in terms of the precision of its notation system (and indeed related the superiority of European culture to the development of the alphabet).

and adumbration, on which ontologies may be mapped. Surveying a number of musical ontologies, Bohlman shows how different concepts of music inform notions of ownership, agency, community, number, language, time, nature, science, the divine, and so on. His fourfold systematisation calls to mind the work of Philippe Descola in Beyond Nature and Culture (2013), while his emphasis on their enactment in practice seems closer to that of Annemarie Mol in The Body Multiple (2002). 
These developments not only distinguished the historical study of the development of western music from the ethnographic study of historically static non-western music cultures, but also led to a very particular music ontology, in which music was not considered first and foremost as a practical activity, at once creative, social, political, sensory, material and emotional, but as a structure of "organised tones", an ideal and transcendent object (rather than a process) as represented by the score. In his 1885 founding programme for the academic study of music, Guido Adler writes that:

In the final and highest instance, however, the history of music looks at artistic creations as such, in their mutual concatenation and their reciprocal influence, without special consideration given to the life and effect of individual artists who have participated in this steady development. (Mugglestone 1981: 7)

The history of music was thus defined as being propelled purely by forces "internal" to the music, leading to what Nicholas Cook has called a history of "composition, or even of compositional innovation" (2014: 3). This also has consequences for performance. With music existing as an ideal object, performance becomes curiously accidental to music's existence. Performers are caught up in a paradigm of "reproduction", which Cook describes as "the idea that performance means bringing out something that is already there in the score, composed into it and just waiting to be released by the performer" (2007: 338). In this paradigm, the demand to play "just the notes" or to stick to the composer's intentions is not just an ethical obligation but an ontological necessity.

The ethnographic study of music was scarcely represented in Adler's programme. The historical study of music, he argued, should be complemented by a "systematic" musicology, which consisted of music-theoretical, philosophical, aesthetic, and psychological questions, and of something he called "comparative musicology", the ethnographic study and comparison of musical systems in different cultures. It was only in the second half of the twentieth century that this field, now called ethnomusicology (Kunst 1955), started to explicitly engage with anthropological theory. The work of Alan Merriam was particularly important for this shift, with his definitions of ethnomusicology changing in the course of the 1960s and 1970s from "the study of music in culture" to "the study of music as culture", and finally stating that "music is culture and what musicians do is society" (cited in Myers 1993: 7).

I am briefly discussing this disciplinary history to highlight an important point for my discussion below: that the concept of music as an academic subject associates it foremost with writing rather than performance, to such an extent that any considerations of social context, cultural meaning, or even the interactions between performing musicians were considered to be strictly "extramusical". It is this odd ontological arrangement that lies at the basis of the distinction between musicology and ethnomusicology, and which gives a very particular significance to the supposed and often constructed opposition between the aesthetic and the social which is a familiar and central problem to anthropologists of art. It is also this ontology that gave rise to the idea that to concentrate on specifically musical issues would not be compatible with a serious engagement with anthropological theory, and vice versa (Kingsbury 1997, Beginho 2008).

Much of this has been addressed in the past 25 years. During the 1990s, musicologists increasingly started to address music's entanglement with social and political issues, as well as the ideological baggage that had prevented this earlier, and ethnomusicology was swept up in the more general reflexive turn in anthropology that problematized the notion of "culture" and the nature of ethnography and fieldwork. In both fields, one outcome of these developments was a 
shift in emphasis towards the concept of performance, to avoid either a work-based approach or a totalising concept of culture, and to foreground the forms of social and creative interaction that were now increasingly seen to be essential to music's existence.

This led Nicholas Cook to argue, somewhat optimistically, that "we are all (ethno)musicologists now" (2008). Noting the increasing overlap between the two fields, he argues for a consideration of how conceptions of race and ethnicity, self and other, and insider and outsider have fundamentally shaped disciplinary programmes. He generalised this idea with his advocacy of a "relational musicology" (2012), an approach that considers musical, personal, cultural and genre identities to be relationally constructed. The "situated encounter" - between musicians, cultures and musical practices, but also between for instance ethnographer and informant - becomes a site that is historically, ideologically and socioeconomically conditioned, but that also allows for a negotiation and perhaps a variation of these conditions, an exercise of agency. The reference to Bourriaud's relational aesthetics here is intentional, since the idea that music creates social relationships, and its correlative deconstruction of the distinction between the aesthetic and the social, is crucial to this relational musicological project. In Cook's words, a relational musicology sees music as "not just a metaphor but a metonym of social interaction" (2012: 196).

Georgina Born, in her formulation of a relational musicology (2010), suggests that the rapprochement between musicology and ethnomusicology should be informed by a larger engagement with social and anthropological theory, as this development has been largely informed by a wish to attend to the social nature of music. She proposes to conceive of music as an assemblage of multiple mediations (more on this below), in order to attend to the constant work that has to be done for music to even exist, and thus to the social relations that sustain and make up musical practice. ${ }^{4}$ In addition to the relationality proposed by Cook, she suggests a comparative approach to the social, technological, temporal and ontological aspects of music, four topics that may provide particular connections to anthropological thought and may help to generate disciplinary innovation. Ontology is particularly important in such interdisciplinary engagement, as it raises not only the question "what music is", but also "what counts as music to be studied" (208-9). In other words, it can not only help to redefine what musicologists study, but also how they study it, and the values and prejudices inherent in such methodologies.

Both Cook and Born's versions of relational musicology attend to the way in which musical ontology is wound up with social practice. This is no less true of the ontology that lay at the basis of musicology. Lydia Goehr (2007) has shown how this "work-based" ontology, which conceives of music in terms of discrete ideal objects represented in writing, came about not only because of the aesthetic changes described by Tomlinson, but also changes in musical practice and the socio-economic position of composers in Europe. In the scholarship on improvised music, this relation between ontology and practice has been much more explicit. Ingrid Monson, in an ethnographic work on the practice and theory of jazz musicians, argues that "Rather than being conceived as foundational or separable from context, structure is taken to have as one of its central functions the construction of social context" (1996: 186).

4 Note the similarity to Howard Becker's (1982) approach to "Art Worlds", and to Latour's (2005) emphasis that the social is in constant formation. Cook (2012) and Born (2005) both draw on Latour's work, and so will I below. However, it should be noted that there are many similarities in what follows to Becker, Faulkner and KirshenblattGimblett's (2006) work on the open-endedness of works of art and particularly Becker and Faulkner's (2009) work on repertoire, both of which have been influential on the wider project of which I present part of my results here. 
Two conclusions can be drawn from this entanglement of ontology and practice. First, that music's existence "between process and product" (Cook 2001) can be a useful object of study to those critical of the focus of material culture on finished and stable objects (Ingold 2011). The second has to do with the purpose of ethnography. Bourriaud's concept of the microtopia has some affinities with Cook's "situated encounter", a place that does not project an entirely new world, but one that creates an interstitial opportunity for agency. Roger Sansi argues that art and ethnography share this utopian element, as they present "a reduced model of a possible world, a research process that proposes to imagine the social in different terms" (Sansi 2015: 157). The purpose of my research project has been to take the concept of "Instant Composition" as a way of scrutinising how the concepts of composition and improvisation have shaped musicological thinking about musical performance as a social process. I will do so below by drawing on statements by the ICP's musicians themselves, but especially on my own observations of their performances and rehearsals and reflections on what their practice may tell us about the role of notation as an object of creative and social interaction. ${ }^{5}$ Relational musicology is committed to such a dynamic unsettling of categories and the reciprocal movement it creates between such empirical work and the methodological assumptions of music scholarship. In other words, Sansi's emphasis on the utopianism inherent in both ethnographic fieldwork and artistic practices, namely their commitment to imagining different ways of being, has both an ontological and an ethical component.

\section{The Instant Composers Pool}

In the early 1960s, when Mengelberg and Bennink started playing together as part of a successful jazz quartet, Mengelberg was a student at the Royal Conservatoire in The Hague, where he would major in music theory. He was one of five students of composer Kees van Baaren - the others being Louis Andriessen, Reinbert de Leeuw, Peter Schat and Jan van Vlijmen-who would become some of the most famous composers of post-war Dutch music, not only because of their musical achievements, but also because of the notoriety they gained from their political activism. In his detailed history of Dutch avant-garde music in the 1960s, Robert Adlington describes how these composers not only encountered experimental music and performance art, which were radically different from anything they had been taught, but partly because of such encounters were also made to consider their social relevance in the face of the emerging counterculture (2013: 23-24).

Through the organisation of demonstrations, debates and the foundation of various institutions, they raised questions about the social organisation of musical life in the Netherlands,

\footnotetext{
5 Over the course of two years, I attended most of the group's performances and rehearsals during this period. This meant brief periods of fieldwork of at most three weeks of regular performances- this corresponds to some degree to the way in which the musicians themselves interact with each other as a group given that some of them live outside the Netherlands (i.e. New York, Berlin) and only meet up with the others to do a series of performances. In addition to this fieldwork, I conducted various interviews with the musicians, using both semi-structured interview techniques and stimulated recall methods using video and audio material of performances and rehearsals recorded in the course of the fieldwork. I did not participate in their music (though this is standard practice in traditional ethnomusicological research) because, as I explain further on, the Orchestra is an established group and not just anyone can join in-my own skills as a musician would also not have been sufficient. Despite this, the musicians did express their feeling that I had become something of a part of their group later on in my fieldwork, a feeling I had come to share. Other than this, I have no official affiliation with the ICP.
} 
including the hierarchies and division of labour inherent in musical practice as well as questions concerning the wider infrastructure of music: pedagogy, programming, funding policies, and so on. In addition, they asked themselves to what extent their own musical practices could not only be organised in such a way as to reflect their political ideals,, but might themselves also have a positive political effect beyond the sphere of performance-in other words: could avantgarde music be a positive political force in society?

Although these developments have usually been described in histories of Dutch composed music, there was a considerable degree of overlap with contemporary jazz and free improvisation (Rusch 2011), where similar questions were being raised about pedagogy, funding and the hierarchies and social conventions of musical practice. The ICP was initially founded partly as an interest group, in order to create better opportunities for improvising musicians. In an interview with the French Jazz Magazine in 1974 Mengelberg stated: "All music is political, our improvised music is political, it is the continuation of our thought, of our political actions" (Unknown Author 1974: 20). In 1977, he was more explicit about this:

I have been working on a democratisation of music itself for years, it is essential. [...] Delegating decisions to performing musicians is an aspect of it. Such delegation is only a weak form. In the Instant Composers Pool the distinction between composer, musician and conductor has virtually disappeared. (Koopmans 1977: 208)

If such remarks seem to indicate a vision of musical performance as a microtopia, it must be emphasised that such questions of social relevance met with much disagreement among Dutch musicians and composers, and the ICP was no exception. Of the three founders, Bennink has never voiced any explicit political commitment, whether in the context of his music or otherwise. Breuker and Mengelberg were more outspoken, but Breuker eventually left the ICP in 1973 partly because of disagreement with Mengelberg about the purpose of democratisation in music. Mengelberg himself frequently disagreed with the other Van Baaren students: "I thought it was a nauseating period. [...] Overstated expectations, hysterical enthusiasm, gauchisme, without much depth" (De By and De Beer 1988: 5).

In addition, even though Mengelberg saw the improvised music of the ICP as a "continuation of our political thought", his view on improvisation was by no means utopian, but aware of the necessary limitations inherent in any form of musical practice. This marks a contrast with the emphasis on "freedom" that was so prominent in the American "Free Jazz" of the 1960s, where breaking the conventional rules of rhythm and harmony was symbolic for the struggle against institutionalised racism in the United States (Anderson 2007). In the 1960s Mengelberg commented: "Such rebelling for its own sake is trivial, it gives you nothing substantial to deal with. You just end up with new forms of discipline" (Vuijsje and Witkamp 1966: 225). In the 1990s he implied that he actually found such music oddly restricting: "They made it into a religion instantly. It had to have power, and whenever it sounded similar to something else it must have been thought of in advance, it had to be spontaneous, etc. I had no use for such slogans. "Free" music was a plague" (Andriessen 1996: 19).

This is one meaning of "instant composition": the acknowledgement of the rules and discipline inherent to improvisation, and also the valorisation of improvisation as a musical practice by emphasising that it involved much the same kind of aesthetic and structural musical considerations as composition. Mengelberg has always maintained that he did not see any difference 
between composition and improvisation in principle, only in terms of procedure:

I think the two matters are barely any different. The processes of consideration of musical activities run parallel to each other. Only the procedure is different: in improvised music you collect an amount of baggage which you can employ on the spot, while as a composer you have to be much more elaborate about it. You sit at a desk and use your baggage to fill a page with music notation, with suggestions of what is to be played by a group of musicians to which you do not necessarily belong to yourself. (Andriessen 1996: 22)

This attitude also meant a greater acceptance of familiar musical material than in other improvising groups, where, as I quoted Mengelberg above, anything that sounded similar to something else was suspected of having been prepared in advance. As Adlington writes, in the practice of the ICP, "musical freedom included the choice of departing from the notion of 'free', as it was fast solidifying in the practice of fellow avant-garde improvisers" (2013: 119).

The duo performances of Mengelberg and Bennink, recordings of which make up most of the ICP's catalogue during the 1970s and which became notorious in the Netherlands because of the musicians' particular stage behaviour, exemplify this point. Their music drew from a large variety of sound worlds, including free jazz and earlier forms of jazz such as swing and bop, but also including tangos, can-cans, classical dance forms, German "Schlager", hymnals and Wagnerian harmonic explorations, all combined in long improvised pastiches. Moreover, the two musicians were playing in opposition to each other as much as (or even more than) collaborating, by ignoring or even intentionally sabotaging whatever the other was doing. Much of the time, it seemed that they were hardly interacting at all. Bennink tended to play very loud and fast, using everything around him that could make a sound, while Mengelberg slowly explored harmonic and contrapuntal structures on his piano. If there were any interaction, it would be primarily antagonistic - they would tease each other, deliberately missing entries set up by the other, playing right through what the other is doing, and joining in with something when the other had already stopped. This form of interaction involved a large sense of theatricality, as Bennink would empty a bag of drum sticks over his kit or knock over his cymbals to make a loud crash while Mengelberg would be dryly waiting to be audible again.

Adlington, although noting the reluctance of the ICP's founders to identify their music too strongly with any political movement, compares this form of musical interaction in the ICP's early performances to a particular strand of individualist anarchism. He discusses the subversive, antagonistic and headstrong behaviour of the musicians and opposes this to the much more conventional emphasis on collectivity in other free improvising groups (both in the USA and in Europe), where integration into a collective production and merged group identity was the aim (Adlington 2013: 127). He compares this to the anarchist ideas of Max Stirner, whose individualist form of anarchism envisaged a "war of all against all" in which collaboration would only be a temporary truce, a "union of egoists" (Adlington 2013: 126-8).

This form of interaction was cultivated also when Mengelberg, toward the end of the 1970s, started putting together a steady group of musicians, which in the course of the 1980s led to the establishment of the "ICP Orchestra", with which most of the creative output of the ICP has since been associated. Both trombone player Wolter Wierbos and alto saxophonist Michael Moore, who have been part of the group since the early 1980s, confirmed this in our 
interviews:

Wierbos: The way of working in the ICP is derived from Han and Misha. They've been working together for so long... or rather against each other, like in a boxing match. [...] That has nothing to do with freedom, it's about egos, competing and showing off. The louder Han would play, the softer Misha would become. And Han wouldn't hear him, and he would become purple and when he stopped you would hear Misha, playing very softly. That was fantastic! (21 December 2011)

Moore: I really appreciate Misha, when he does choose people for his band, he doesn't just choose people that have a similar aesthetic. [...] Misha, he liked to create tension in any way possible, and in the beginning a lot of it was... putting people together that perhaps shouldn't be together, you know! Seeing what would happen! You know, people that really wouldn't like each other he would put together. (23 December 2011)

In order for the iconoclastic interaction of the Bennink-Mengelberg duo to work in a group of around ten musicians, Mengelberg started to compose a large repertoire of compositions. Although he had always written music for the ICP, he now started to do so on a large scale, and the group would have rehearsals every week to become familiar with this material. This repertoire includes a diversity of styles and uses various forms of notation, including regular staff notation, the chord changes of common jazz practice, graphic scores and other indeterminate notation systems like mobile forms. Before each set, a set list is made from a small selection of this repertoire as well as specified groups of musicians who do brief free improvisations together, and the ideal is to play a whole set without any pauses, improvising transitions between items on the set list, suddenly lapsing into a free improvisation in the middle of a composition, or interrupting one piece with another.

This liberal use of notated music in their improvised performances points to a second meaning of "instant composition". Mengelberg had been part of the Fluxus movement in the early 1960s, at the time that Fluxus artist Tomas Schmit was creating a series of "instant poems", jars filled with scraps of papers, letters, or even ash and ink, to be "shaken well before reading", creating a collage of found poetry (Wien, Lukatsch and Vollmer, no date). Similarly, the musicians of the ICP create an improvised collage of their repertoire, using the notations as "found objects", as Moore put it (23 December 2011). This practice means that the scores in the ICP's repertoire function as significant sources of creativity for the performers. Rather than establishing uniformity and reaffirming the control of a composer as in the discourse and practice of the "work-concept", the pieces in the ICP contribute to the heterogeneity of creative possibilities open to the performers.

The first meaning of instant composition-which is not exclusive to the ICP, or even to European improvisation-entails an understanding of improvisation that subverts its status as an "Other" to Western, rational and text-based art music by countering its associations with the primitive and the irrational (such an argument is central to Berliner 1994). This point is now more widely accepted, and it is perhaps no longer as necessary to argue for it as it was in the 1960s. The second meaning, which I will discuss in more detail below, suggests a potentially more radical opportunity of reconsidering the function and use of musical notation in ways other than the Platonic, composer-centred manner of the work-concept. It is in this sense that I will discuss the ICP's practice as a "microtopia", in terms of the possibilities for imagining different ways of being. The ICP's repertoire and its use present an opportunity to reconsider ontological assumptions about text and performance, and the way in which such assumptions guide ideas about art as a form of social interaction. 


\section{InStant Composition}

The ICP's repertoire forms what Alfred Gell (1998) calls a "distributed object", and what Lucy Suchman (2005) calls an "affiliative object". It is distributed not only in the sense that it consists of various pieces, but these pieces themselves are spread out over various copies, versions, and instrumentations, or split into various parts. The musicians all have big folders with these notations, some of which contain their own markings and scribblings. During my fieldwork I collected my own folder, which at around 100 separate pieces is about half the size of the folders carried by any of the ICP's musicians. These folders are not meticulously kept archives; on the contrary, it often happens that the group wants to play a piece and somebody does not have (or cannot find) their copy or part-which would be an opportunity for me to make a copy. During my fieldwork it happened frequently that a musician (some of which have been in the group since the early 1980s) would dig up a piece that they had not played for decades. Some instructions would no longer be clear, and such arrangements usually had outdated instrumentations.

It is because of this distribution and multiplicity that such pieces also become affiliative objects, "fraught with significance for the relations that they materialize" (Suchman 2005: 379). They become objects of social interaction as the musicians figure out how to interpret certain markings that may have been made in the context of particular performances in the 1980s, or how to divide the various parts among the current line-up. Some of the musicians may make the effort of writing a new arrangement of an old piece, which because of the addition of a new introduction or coda, or new suggestions for improvisation also creates new possibilities of playing such an old piece together. One of the most frequent forms of collaboration on the ICP's repertoire is the making of set-lists. These are always made briefly before the set-the list for the first set may be made over dinner at the earliest, but the second set is always made during the 20-minute interval and so requires musicians to quickly find their scores, copy any missing parts or determine if they can play something by heart.

These set lists used to be made by Mengelberg. Tenor saxophonist Ab Baars describes them:

A few minutes before the concert he'll take a pen and a slip of paper, puts together some groups of people that will improvise, and around that he'll construct the programme, of the pieces that we play. And I've noticed he'll always take into account the keys the pieces are written in, their atmosphere. Making such a programme is also composing, in a sense. Those set lists are always gratifying, and you can do a lot with them. (Dekker 2005)

As Mengelberg's health began to deteriorate because of old age, the musicians have increasingly taken over the making of set lists. A set list will include a selection of pieces, possibly names of musicians who may take a solo in a particular piece, and groups of people that will improvise together freely. Making a set list gives some insight into how the musicians' relationships to these objects become negotiations of social relationships, as they are opportunities for musicians to exercise their personal tastes for swinging and symphonic arrangements of Duke Ellington pieces, anarchic improvisation games or sparse atonal chamber pieces. Moreover, they can decide who can take a solo in a piece either because they think the piece fits their playing style or precisely because it will form a challenge for them. In outlining such soloists and improvising groups it is an unwritten rule that everyone gets an equal chance to play. 
The role of the repertoire in the social interaction between the ICP's musicians is not restricted to such collaborations around performances, but also permeates their socio-musical interaction on stage. From a musical point of view, their notations participate in the creation of musical structure in performance. From a more ethnomusicological or anthropological point of view, this means that the notations mediate the social and creative agency of the musicians during performance. As I described above, the work-based musicological paradigm of reproduction almost turns performance into an accidental property of music, and the agency of performers in the creation of music has therefore long been neglected. Conversely, discourse on improvised music has long emphasised the agency of performers in the musical process, and has perhaps at times overemphasised improvisation as a form of spontaneous and immediate creation in opposition to performers who simply "follow a score" (Cook 2007). Both discourses are deeply shaped by distinctions between literacy and orality, and both take a negative view on notationin the sense that the score is perceived as a site of negation of agency.

The practice of the ICP, in which notated pieces are used precisely to create new opportunities for improvisation, offers an alternative. The iconoclasm of the Mengelberg-Bennink duo and the ICP Orchestra is similar to the kind of iconoclasm that Latour associates with ActorNetwork Theory, in which iconoclasts

... do not believe it possible nor necessary to get rid of images. What they fight is freeze-framing, that is, extracting an image out of the flow, and becoming fascinated by it, as if it were sufficient, as if all movement had stopped. What they are after is not a world free of images, purified of all the obstacles, rid of all mediators, but on the contrary, a world filled with active images, moving mediators. (Latour 2002: 26)

A particularly good example of this is a set of compositions that the ICP's musicians call "viruses". Viruses are very short pieces, for instance a melody of a few bars, a repeating riff, or a small graphic score, that can be initiated by any musician at any point, and so they usually do not feature on a set list. They are called "viruses" because they can spread by "contamination" (other musicians take over the virus) and so overtake whatever is happening at that point; either another piece or a group improvisation, or it may be "contained" and then it is no longer a threat.

The use of these viruses is a good example of how compositions in the ICP do not determine the actions of the musicians, but may be used precisely to subvert what other musicians are doing, who then have to adapt to what is happening in the group. The metaphor of the virus, to the extent that it connotes something that sits on the boundary of what can be considered a living organism, and which is dependent on a host organism for replication, can also be taken as an indication of the agency of these pieces. They infect the behaviour of the musicians, and do not participate in the musical interaction as a musician would, but rather they have an impact on a more systemic level. This actually makes them effective tools for musicians to change the musical situation rapidly: if a musician wants to go in a new direction while playing a particular piece, they can of course do so by simply playing something else (and this happens frequently in the practice of the ICP). But these viruses, however minimal some of them may be, lay down more of a "ground" for interaction with which other musicians can collaborate, or from which they may in turn diverge.

The idea of the "virus", however, is not restricted to this set of pieces. Over time, the group has developed inventive ways of radically reinterpreting aspects of their scores, not only varying the tempo, playing lines from other musicians, playing lines backwards, suddenly chang- 
ing from minor to major, but also reinterpreting clefs, rests and the letters in titles as "graphic scores". As tenor saxophonist Tobias Delius pointed out to me, the viruses exemplify this more general way of working in the group:

Some have a name, and then we have decided to keep it and use it more often. But this principle is always there-it's always possible for everything to suddenly go in a different direction. Viruses can be composed by Misha, or spontaneously invented on the spot. They can grow from misunderstandings. [...] It can also be something very banal, pointing at the score and saying "let's play this backwards". Or pointing at a sign for repeating a bar and reading it as a graphic score-beep, booyee bap-or even a title, or a word as a graphic score, or the rhythm of a word or a phrase. (21 February 2012)

This is partly what Michael Moore referred to as taking these pieces as "found objects", and it is indeed a practice that depends on seeing these texts as material objects rather than representations of abstract structures. The practice Delius describes always takes place among a part of the orchestra, never the whole group: for instance between two or three musicians standing next to each other, between the group of brass or string musicians. It often hinges on traversing the line between (to use Peirce's semiotic terms) symbolic and iconic signification. A downward arrow, originally intended to mean "once you have played this, you can skip forward to here", can be reinterpreted as a graphic score and be played as a downward glissando. A note or melodic line that has been scratched out can become "play some chaotic noise". The swirling and wriggling shape of a G-clef symbol can be reinterpreted as a swirling and wriggling melodic line. Such playful reinterpretations-which Delius calls "a little banal" but, it seems to me, actually depend on a kind of virtuosic co-responsiveness that is seen more often amongst improvising musicians, and perhaps amongst expert collaborators more generally—can be used like viruses, to create chaos or to suddenly go in a different direction. Conversely, they may be used to spur on a soloist by creating a background, or they may be contribute a particular texture to an improvising group or in an improvised transition from one piece to the next. Crucially, it shows one of the ways in which the musicians improvise precisely by playing something that has been written down.

Delius further explained how this altered the role of their notations compared to the more traditional use and discourse of the relation between notation and performance:

Many people say that improvisation can be too chaotic and then there is the "guiding hand" of the composer or a piece to bring some sense of structure, but I think it's the other way around. The purpose of the written material is to disrupt a "nice flow" of improvisation. It can create more anarchy than improvisation sometimes. [...] The compositions play their own part. (31 January 2013)

What Delius points out is that instead of determining the musical process, the compositions in their repertoire can be used to take things in new directions and explore unforeseen musical possibilities. This is an explicit and direct counterargument against the work-concept as employed traditionally in musicology. This work-concept may be seen as an extreme version of what Tim Ingold has called the "hylomorphism" that guides much thinking about creativity: the idea that creative work is about applying a preconceived model or plan rather than realising that such structures emerge in the course of such creative work (Ingold 2011: 210-219).

Lucy Suchman made a similar claim in her work on human-machine interaction, in which she tries to formulate an alternative to the view that "treats a plan as a sequence of actions designed to accomplish some preconceived end" (Suchman 1987:28). The problem with this view is that it neglects the necessary improvisation inherent in action, and the fact that plans, taken 
as representations of action, are created in the course of this improvisatory activity, in order to make sense of it (51). Like Ingold, she argues that "the organization of situated action is an emergent property of moment-by-moment interactions between actors, and between actors and the environment of their actions"(179). For my purposes, she makes an important next step however, by arguing that plans (in her case instructions to novice users of complex machines) can be understood as "resources for action" (185 ff.). As representations, they are themselves artefacts that form part of the environment to which an actor responds $(2005,389)$, and they may be used to reflect on earlier actions or precisely to open up new possibilities. As Delius put it, speaking of Mengelberg's arrangements of Duke Ellington: "When Misha arranges such a piece $[\ldots]$ there are built-in moments from which... where it's not about erasing the composition but about improvisationally shaping the material" (31 January, 2013).

The indexicality of signification, its context-dependence, is crucial to the role of notation in such an improvisatory practice. It suggests that the meaning of the written sign is not contained in the score, "waiting to be released by the performer" as Cook put it, but emerges in the course of performance. Indexicality is central to Gell's account of creativity and distributed objects, as it is through such relations of indexicality that artworks are entangled in networks of agency. Born's relational musicology draws significantly on Gell's work, and notes ways in which music might contribute to Gell's theories as set out in Art and Agency. Music, Born argues, requires an account of mediation that is largely missing from Gell's theories. "Music favours associations between musicians and instruments, composers and scores, listeners and sound systems, music programmers and digital code-that is, between subjects and objects" (Born 2013: 138). It is this "plural and distributed material being" that music presents to us that "indicate[s] the necessity of conceiving of the musical object as a constellation of mediations" and of "its meaning, and of musical experience, across these plural mediations" (138-9). However, to fully account for all the material actors that may be part of such networks, Gell's notions of abduction and the protentions and retentions between particular objects are not sufficient. This requires attention to mediation, in order to see how objects are "device[s] of generating relations, or in other words of generating agents, not just of tracing them back" (Sansi 2015: 55).

As an illustration of how notation is involved in such networks of mediation, and not just in binary relations between score and performer or text and performance, I will briefly discuss the notion of instrumentation. The "voice" of a musician, as developed through the skill of playing an instrument, is a good example of the mediation of agency more generally. In addition, an instrument usually implies a particular "role" for a musician in an ensemble, for a combination of historical reasons and reasons of material construction. For instance, drummers, bass players and pianists in jazz are expected to be very well attuned to each other since they, as the "rhythm section", provide the rhythmic and harmonic foundation for the rest of the group. Similarly, the division in the ICP Orchestra of a brass section on the right of the stage and a string section on the left may be understood to signify the encounter between jazz and classical music that is enacted in their practice.

The score constructs relations between musicians by specifying groups of musicians to interact closely with each other, and by imagining, assuming or inventing particular playing styles for them. I already described how the negotiation of obsolete instrumentation forms part of the social interaction between the ICP's musicians. The mediating role of instruments in the agency of notations may be seen in an example from the ICP's rehearsal of new material. In trumpeter Thomas Heberer's "Coming up for Air", Heberer included a section where the musicians could 
play a call and response figure at will, but it was his intention that they do this while the rhythm section would continue to provide a rhythmic basis. During the first rehearsal of this piece, he interrupted everyone and the following exchange occurred between him and bass player Ernst Glerum:

Heberer: There is a confusion that has to do with the way I wrote it. For the rhythm section in the D part, it's continuous. It's like a no chord situation, but you continue with the walking bass, so... those little crosses are just backgrounds if you want.

Glerum: I can't play background (?).

Heberer: Oh y-you could, if you wanted to but eh-it would be...for somewhere where the rhythm section has to function...

Glerum: No, no, sure, I'll play notes. I just wanted to...

$[\ldots]$

Heberer: Let me rephrase that Ernst, if you feel like doing it, that is perfectly fine, but that was not the original idea, so I think from that perspective, it would be slightly... it would be a slightly different thing.

Glerum: No worries man, sure. (30 August 2012)

It is an interesting exchange because it illustrates some of the tensions between the egalitarian impulse of improvisation and the authorship and authority that are inherent to bringing a new piece to rehearsal and explaining how to play it to the group, which explains Heberer's apologetic tone. However, what I wish to focus on is that the confusion stems partly from Heberer's assumption in writing the score that the rhythm section would continue to provide a ground for the rest to improvise with the call and response patterns, and Glerum's expectation that this would be an opportunity for him to stop providing this ground and join in with the improvisation. Of course, as Heberer says, Glerum can in fact choose to join in with the call and response patterns, "that is perfectly fine", but because of the bass player's role of providing a foundation in a jazz piece like "Coming up for Air", this does have direct consequences for the way that the other musicians interact with each other.

Alto saxophonist Michael Moore wrote another piece, "Oz", of which the introduction consisted of downward melodic lines plucked by the string instruments. Notes were suggested, but the musicians could pick their own tempo and were not expected to play their lines together, creating an open, pointillistic texture. Because of this openness, not only in the sound quality but in the way that the musicians are able to pick their own way of playing the suggested notes, this introduction is very suitable for the kind of transitions that the ICP frequently makes. In an improvisation (by the string players or others) the strings can simply start playing these downward lines, which because of the light texture they create does not impose too much on what is happening at that moment but still allows others to accommodate to making this segue.

Again, there is the matter of authorship and authority here, which Moore nicely negotiated by creating this open texture for the introduction. The string players can start the piece on their own accord; nobody needs to count them in or give them a cue. Indeed, they do not need to start playing together but can just join in one by one. During the first rehearsal, after Moore had explained his piece and the musicians had briefly rehearsed the various sections, the group played the whole piece once for the first time. There was no need for Moore to tell them when to start; in fact he was still having a chat with Baars sitting next to him while the string players started their downward lines. In this way, the score mediates Moore's agency as an author as the musicians can engage with the written music on their own account without Moore having to 
tell them what to do.

The style of this introduction is more reminiscent of contemporary chamber music, which is another key part of the ICP's sound world besides jazz. This is actually suited particularly to the string players (Mary Oliver, Tristan Honsinger and Ernst Glerum), who all have a classical conservatory education, and Oliver and Glerum have actually had careers playing contemporary composed music. A more significant way in which the instrumentation of this introduction mediates the interaction in the group is that it allows the string players to initiate a transition very effectively. Strings are softer than brass and reed instruments, and the string players regularly told me that when a piece or improvisation gets particularly loud, they can find it difficult to contribute something to the music. The strings also initiate viruses less frequently, because they simply do not have the volume to be audible in some situations. "Oz" thus gives them an effective way to take the music in a sudden new direction because the plucked downward lines are so clearly recognisable that it will be instantly clear to everyone that they are starting a transition to "Oz". If a string musician would otherwise start plucking a downward melody, this would not have so much impact. The piece thus creates new possibilities for the string musicians to influence the socio-musical interaction on stage.

\section{Conclusion}

Those familiar with the debates surrounding relational aesthetics will have recognised many similar themes: questions of art as process or product, the politics of the process of making, of authority and participation and the question of collectivity and antagonism. To conclude, I will briefly draw out some issues regarding the politics of participation in the ICP more explicitly. Compatible with Adlington's portrayal of the ICP's similarities to individualist anarchism, significant emphasis was placed on individual responsibility in the discourse of the musicians during our interviews. In many of their statements, the way they phrased this responsibility made it unclear whether this was an aesthetic or ethical responsibility, suggesting that these two largely overlap for the ICP's musicians. As Ab Baars indicates, referring to the early beginnings of the ICP Orchestra, when Mengelberg was trying to create a particular way of working in the group, this individual responsibility was always tied to an awareness of one's role in a collective effort:

Misha wanted us to do our own thing, but he corrected us often, and he was really trying to go in a new direction, where we would steer the material as a group, not as an individual, but that everyone had a compositional mind-set. Everyone could introduce something new, but with conviction, and taking responsibility for what he or she did. (4 January 2012)

As noted above, the "collectivity" in the ICP is by no means a conformist or egalitarian one, but one that emphatically advocates agonism and discord. It is for this aspect that the emphasis on individual responsibility is particularly relevant. Heberer indicates that the twoagonism and responsibility-necessarily go together:

There is a lot of freedom, as long as you're willing to defend your position. If you throw something into the pool, or change the direction, you have to find a way to make it work or when it doesn't find a way to deal with the failure. (20 February 2012) 
Rather than a particularly demanding or competitive form of individualism, the possibility of failure is accepted as an inherent part of this way of working, as Heberer told me later:

This band is also about tolerating failure. [...] I think the quality sometimes actually lies in the weaknesses and it going terribly wrong and then figuring out how you deal with them, and that in itself can be a quality that one can enjoy, or say it is terrible rubbish but it's not... the rubbish is as important as the really fantastic beautiful Michael Moore solos. That is as valid as the fuck-up of the day. There's no hierarchy in this regard. That is something maybe not specifically ICP, but certainly a specific of the band. (15 July 2013)

The question of antagonism and collectivity is a central one in the debate between Bourriaud and Claire Bishop. Where Bourriaud advocates art practices that create possibilities for interaction and collaboration, Bishop argues that these may only serve to acknowledge the exclusionary political structures in which such artistic practices find themselves, and on which they may to some degree depend. Bishop in turn advocates artworks that antagonise and question the whole premise of identity, harmony and collaboration being a condition for democracy. In the case of the ICP, it seems that these two positions are not mutually exclusive: the antagonism that characterises their practice is clearly dependent on a pre-established agreement on a way of working. One may see this as a refutation of Bishop's point: once the disruption of the premise becomes the premise, there is no stepping outside of the authority of the artist.

The issue is particularly relevant in relation to Mengelberg's status as the leader of the group, which may seem to run counter to the improvisatory intentions that underlie a practice such as the ICP's-even the anarchism that Adlington perceives in their practice only accepts leadership on a temporary basis. (It is worth repeating that none of the musicians has ever explicitly stated that the group is anarchist in any serious sense, but Adlington's analysis is apt and serves to illuminate some aspects of their practice). Even if the musicians play subversive, anarchic performances, there seems to be a certain parochialism in the fact that they do so because this practice was developed under the leadership of Mengelberg-indeed all of the musicians would probably say that, especially now that Mengelberg has stopped performing, the performance practice and aesthetic of the ICP is partly in his spirit. ${ }^{6}$

These are valid points, and rather than to argue against them I would shift the view somewhat to the question of skill. Mengelberg is quite right in saying that there is no practice of improvisation without discipline. To play music, particularly to improvise, is impossible without the development of some practical skill —or perhaps without skill developing in the process. Similarly, although the Orchestra frequently plays with guest musicians, there is a sense in which this repertoire must be acquired before a musician can fully participate in their way of working. In this regard we encounter a major difference between musical avant-gardes, particularly experimental and improvisatory ones, and artistic avant-gardes in the twentieth century. Sansi notes that many artistic avant-gardes since Duchamp and Dada have questioned the importance of skill and have in different ways celebrated the amateur. The relational and participatory art practices described by Bourriaud and to a lesser degree by Bishop also usually involve some form of audience participation.

6 I alluded earlier to Mengelberg's deteriorating health. He stopped performing altogether shortly after my fieldwork had formally ended. 
Music has a rather different history in this. ${ }^{7}$ In his description of how the ICP democratises performance, Mengelberg tellingly speaks of erasing the distinctions between composer, musician and conductor, but not between performer and audience. The same is true of other forms of improvised music: although they almost without exception draw attention to music as a form of social interaction, very few involve audience participation, and many are very exclusive in the sense that they demand a high skill level from performers. The musicians in the ICP are all highly virtuosic performers, and in this sense it is quite an exclusive group. In the course of the 1970s, other groups that had sought to democratise through the participation of unskilled musicians, for instance workshop orchestras teaching improvised music, were finding it increasingly difficult to combine their democratic ethos with a desire for musical quality (Bouman 1978). Mengelberg never had such problems because he always set high demands for performers.

Although this can be exclusionary to some extent, it also makes the ICP's practice possible. Their repertoire, though it has to be learned in order to participate fully, is at the same time precisely what makes possible their particular form of interaction, including its possibilities for antagonism and disruption. The ICP could similarly not function with amateurs, not only because some reading skill is necessary but also because the ability to make such quick transitions and to adapt to each other or subvert each other in innovative ways requires virtuosity. The ICP's repertoire stands out as not only making the premises of musical interaction amongst musicians explicit, but also for allowing them to engage with it on their own terms. In the sense that the ICP actually acknowledge and address their own forms of exclusion, their politics are closer to Bishop's than to Bourriaud's.

Sociologist Pascal Gielen (2013) argues that the idea that creativity is synonymous with improvisation, where artists are expected to constantly adapt to new environments, fits the neoliberal agenda and its sizing down of the arts budget to encourage the "entrepreneurship" of artists remarkably well. The challenge set by Gielen is to create institutions that provide a point of reference, a place for learning and the development of creative skills and knowledge, while they remain sensitive to the power dynamics, the forms of exclusion and privilege that they may enact in establishing such institutions and in the work that is needed to maintain them. The ICP's repertoire, as something that provides a secure basis for the performance practice of its musicians, and yet allows people to engage in agonistic forms of improvisatory interaction, to step away from this repertoire or radically interpret its function, seems a good example of this as it not only imagines a particular model for social and creative behaviour, but also maintains a realism concerning its own limitations.

I have described how this repertoire mediates the socio-musical interaction in the ICP's performances. This practice requires a rethinking of the ontology of text, performance and improvisation, and of the way in which we associate these categories with particular forms of social interaction. This imaginative aspect of ethnography, the unsettling of received disciplinary epistemologies and ontologies, is part of what makes fieldwork so valuable as a method. Bishop argues that the "positivist social sciences" are less suited to deal with participatory art than political philosophy (2012: 7), as such practices always involve an imaginative symbolic

7 It may be thought that the work of John Cage and other experimentalists achieved such a deskilling of the artist, and although there were indeed some attempts to create music for amateur performers in this vein, Cage himself-despite some of his statements to the contrary-could actually be very particular about what he wanted from performers and how his pieces should be interpreted (Piekut 2011: 140-176). 
modality. If we accept that fieldwork is a microtopic imaginative practice rather than a purely positivist one, then such situated encounters may precisely be the most fruitful source of disciplinary innovation.

\section{References}

[no author]. 1974. "Allemagne Pays-Bas: Peter Brotzmann Han Bennink Misha Mengelberg." Jazz Magazine 220: 19-21.

Adlington, Robert. 2013. Composing Dissent: Avant-Garde Music in 1960s Amsterdam. Oxford: Oxford University Press.

Anderson,Iain. 2007. This is Our Music: Free Jazz, The Sixties, and American Culture. Philadelphia: University of Pennsylvania Press.

Andriessen, Bas. 1996. Tetterettet: Interviews met Nederlandse improviserende musici. Ubbergen: Tandem Felix.

Becker, Howard. Art Worlds. London: University of California Press, 1982.

Becker, Howard, Robert Faulkner and Barbara Kirshenblatt-Gimblett. 2006. Art from Start to Finish: Jazz, Painting, Writing and Other Improvisations. London: University of Chicago Press.

Berliner, Paul. 1994. Thinking in Jazz: The infinite art of improvisation. Chicago: University of Chicago Press.

Beginho, Michelle. 2008. "Why I'm Not an Ethnomusicologist: A View from Anthropology." Pp. 28-39 in The New (Ethno)musicologies, edited by Henry Stobart. Plymouth: The Scarecrow Press.

Bishop, Claire. 2004. “Antagonism and Relational Aesthetics.” October 102: 51-79.

- 2012. Artificial Hells: Participatory Art and the Politics of Spectatorship. London: Verso.

Bohlman, Philip. 1999 “Ontologies of Music.”Pp.17-34 in Rethinking Music, edited by Nicholas Cook and Mark Everist. Oxford: Oxford University Press.

Born, Georgina. 2005 "On Musical Mediation: Ontology, Technology and Creativity." Twentieth-century music 2(1): 7-36.

- 2010. "For a Relational Musicology: Music and Interdisciplinarity, Beyond the Practice Turn." Journal of the Royal Musical Association 135(2): 205-243.

—. 2013. "Music: Ontology, Agency, Creativity." Pp. 130-154 in Distributed Objects: Meaning and Mattering after Alfred Gell, edited by Liana Chua and Mark Elliott. New York: Berghahn.

Born, Georgina, Eric Lewis and Will Straw. Forthcoming. Improvisation and Social Aesthetics. Hanover, NH: Wesleyan University Press.

Bouman, Eva. 1978. Workshops: Opkomst en Ontwikkeling. Zeist: Trezoor.

Bourriaud, Nicolas. 2002. Relational Aesthetics. Paris: Presses du Réel.

By, Henk de and Roland de Beer. 1988. "Omdat de instrumenten er stuk van gingen." De Volkskrant, supplement “Kunst \& Cultuur”, 1 April 1988: 5.

Cook, Nicholas. 2001. "Between Process and Product: Music and/as Performance." Music Theory Online 7(2). Retrieved 29 May 2015 (http://www.mtosmt.org/issues/mto.01.7.2/ mto.01.7.2.cook.html).

- 2007. "Making Music Together, or Improvisation and its Others." Pp. 321-341 in his Music, Performance, Meaning: Selected Essays. Aldershot: Ashgate. 
2008. "We are All (Ethno)musicologists Now" Pp. 48-70 in The New (Ethno)musicologies, edited by Henry Stobart. Plymouth: The Scarecrow Press.

- 2012. "Anatomy of the Encounter: Intercultural Analysis as Relational Musicology." Pp. 193-208 in Critical Musicological Reflections: Essays in Honour of Derek B. Scott, edited by Stan Hawkins. Farnham: Ashgate.

- 2014. Beyond the Score: Music as Performance. Oxford: Oxford University Press.

Dekker, Jellie (dir.). 2005. Afijn: Misha Mengelberg. Hilversum: NPS.

Descola, Philippe. 2013. Beyond Nature and Culture, translated by Janet Lloyd. Chicago: University of Chicago Press.

Faulkner, Robert and Howard Becker. 2009. “Do You Know...?” The Jazz Repertoire in Action. London: University of Chicago Press.

Fischlin, Daniel and Ajay Heble. 2004. "The Other Side of Nowhere: Jazz, Improvisation, and Communities in Dialogue." Pp.1-41 in The Other Side of Nowhere, edited by Fischlin and Heble. Middletown: Wesleyan University Press.

Gell, Alfred. 1998. Art and Agency: An Anthropological Theory. Oxford: Clarendon Press.

Gielen, Pascal. 2013. Creativity and other Fundamentalisms. Amsterdam: Mondriaan Fund.

Goehr, Lydia. 2007 [1992]. The Imaginary Museum of Musical Works: An essay in the philosophy of music. Oxford: Oxford University Press.

Hallam, Elizabeth and Tim Ingold. 2007. Creativity and Cultural Improvisation. Oxford: Berg. Ingold, Tim. 2011. Being Alive: Essays on Movement, Knowledge and Description. Abingdon: Routledge.

Kingsbury, Henry. 1997. "Should Ethnomusicology be Abolished? (Reprise).” Ethnomusicology 41(2): 243-249.

Koopmans, Rudy. 1977. Jazz: improvisatie en organisatie van een groeiende minderheid. Amsterdam: SUA.

Kunst, Jaap. 1955. Ethno-musicology. The Hague: Martinus Nijhoff.

Labaree, Robert. 2013. "Living with the I-word: Improvisation and its Alternates." Critical Studies in Improvisation 9(2). Retrieved 29 may 2015 (http://www.criticalimprov.com/ article/view/2204/3267).

Latour, Bruno. 2002. "What is Iconoclash? Or: Is There a World Beyond the Image Wars?" Pp. 14-37 in Iconoclash: Beyond the Image Wars in Science, Religion and Art, edited by Bruno Latour and Peter Weibel. Cambridge MA: MIT Press.

- 2005. Reassembling the Social: An Introduction to Actor-Network-Theory. Oxford: Oxford University Press.

Mugglestone, Erica. 1981. "Guido Adler's 'The Scope, Method and Aim of Musicology'(1885): An English translation with an historico-analytical commentary." Yearbook for traditional music 13: 1-21.

Mol, Annemarie. 2002. The Body Multiple: Ontology in Medical Practice. Durham: Duke University Press.

Monson, Ingrid. 1996. Saying Something: Jazz improvisation and interaction. Chicago: University of Chicago Press.

Myers, Helen. 1993. “Introduction.”Pp. 3-15 in Ethnomusicology: Historical and Regional Studies, edited by Helen Myers. London: Macmillan.

Nooshin, Laudan. 2003. "Improvisation as "Other": Creativity, Knowledge and Power: The Case of Iranian Classical Music." Journal of the Royal Musical Association 128(2): 242-296

Piekut, Benjamin. 2011. Experimentalism Otherwise: The New York Avant-Garde and its Limits. London: University of California Press. 
Prouty, Kenneth. 2006. “Orality, Literacy and Mediating Musical Experience: Rethinking Oral Tradition in the Learning of Jazz Improvisation.” Popular Music and Society 29(3): 317334.

Rusch, Loes. 2011. "Common Ground: 1970s improvised music as part of a cross-genre Dutch ensemble culture.” Jazz Research Journal 5(1-2): 123-141.

Sansi, Roger. 2015. Art, Anthropology and the Gift. London: Bloomsbury Academic.

Schuiling, Floris. 2015. Animate Structures: The Compositions and Improvisations of the Instant Composers Pool Orchestra. PhD dissertation, University of Cambridge.

Stanbridge, Alan. 2008. "From the Margins to the Mainstream: Jazz, Social Relations, and Discourses of Value." Critical Studies in Improvisation 4(1). Retrieved 29 May 2015 (http:// www.criticalimprov.com/article/view/361/960).

Suchman, Lucy. 1987. Plans and Situated Actions: The problem of human machine communication. Cambridge: Cambridge University Press.

- 2005. "Affiliative Objects." Organization 12(3): 379-399.

Tomlinson, Gary. 2012. "Musicology, Anthropology, History." Pp. 59-72 in The Cultural Study of Music: A Critical Introduction, edited by Martin Clayton, Trevor Herbert and Richard Middleton. London: Routledge.

Vuijsje, Bert and Anton Witkamp. 1966. "Een Jazzwereld Diskussie”. Jazzwereld 7: 224-229.

Wien, Barbara, Wilma Lukatsch and Kai-Morten Vollmer. "1963." Tomas Schmit Archiv. Retrieved 29 May 2015. (http://www.tomasschmit.com/index.php?id=53).

Date received: 2015-05-31

Date accepted: 2015-12-02 